\title{
Conflict of Laws
}

\section{Oxford Colloquium on collateral and conflict of laws}

\section{by Richard Potok}

Every day somewhere in the vicinity of $£ 1$ trillion of the world's debt and equity securitics are provided as 'collateral' (the term collateral is used loosely to cmbrace not only security interests but title transfer arrangements, including repurchase agreements, intended to fulfil a security function) for loans and other credit exposure extended by financial institutions; The collateral provided is typically interests in respect of fungible securitics that are held through, and reflected on the books of, financial intermediaries. Such interests can be referred to as 'intermediated book-entry securities.' As is true with all collateralised obligations generally, financial institutions are normally only willing to make these loans and extend this credit if they have a 'perfected' interest in the collateral that is good against third parties in the event of default by the borrower. Yet in today's global economy, this collateralisation increasingly involves cross-border transactions, raising difficult conflict of laws questions ${ }^{1}$.

Since at least the market crash of 1987 , there have been fears that existing commercial laws and conflict of laws principles - usually designed for securities held directly by an investor (i.e., by physical possession of a bearer certificate or registration on the register of the issuer) - do not afford the certainty and predictability desirable for the provision of intermediated bookentry securities as collateral in crossborder situations ${ }^{2}$.

Attention to these developments has led to a number of initiatives. In Belgium and Luxembourg, the securities transfer and pledging laws were clarified to increase the legal certainty of collateral transactions involving Euroclear, Cedel Bank and certain other financial intermediaries, and the conflict of laws rules applicable thereto. In Europe, art. 9(2) was included in the EU Directive on Settlement Finality in Payment and Securities Systems (Directive 98/26 (OJ 1998) L166: the 'EU finality directive') to specify the conflict of laws rules applicable to various collateral transactions in EU settlement systems. In the US, art. 8 and related sections of the Uniform Commercial Code ('UCC') have been extensively revised, among other things, to increase the certainty and predictability of the legal rules relating to collateral transactions through all financial intermediaries, including the conflict of laws rules applicable thereto.

English courts have yet to consider fully the conflict of laws rules applicable to the modern system of holding bookentry interests in a pool of fungible securities through financial intermediaries (Macmillan Inc v Bishopsgate Investments Trust plc (No. 3) [1996] 1 WLR 387, which involved indirectly-held as well as directly-held securities, did not address the issue of the conflict of laws rule applicable to intermediated book-entry securities). The decisions that exist have indicated that, in the case of bearer securities held directly by investors, the focus is on the location of the physical certificates or, in the case of registered securities, on the place of the issuer's register or the place of incorporation of the issuer. Yet with London positioned as one of the world's principal international financial centres and with the English conflict of laws rules followed in many common law jurisdictions, there is an urgent need for clarification of the English conflict of laws rules with respect to intermediated book-entry securities used as collateral.

On 1 May 1998, 25 leading academics and practitioners from England, Europe, the US and Australia, with collective expertise in conflict of laws, custody and settlement law, commercial law and trusts law gathered at St John's College, Oxford, to consider this problem and determine whether English law in its current form can provide the level of certainty necessary for a major financial centre. The Oxford Colloquium was held under the auspices of the Oxford University Law Faculty and the Institute of Advanced Legal Studies and was organised by Allen \& Overy.

\section{THE PARTICIPANTS}

Experts in most relevant areas of English law participated in the Colloquium. The Colloquium was chaired by Dr Lawrence Collins QC, the general editor of Dicey \& Morris, The Conflict of Laws ('Dicey \& Morris'). Two of Dicey \& Morris's contributing editors, Professor Robin Morse and Adrian Briggs, also participated, as did other conflict of laws luminaries, Professor Francis Reynolds QC, writer of Bowstead and Reynolds on Agency and editor of the Law Quarterly Review; Philip Wood, a leading practitioner from Allen \& Overy; Richard Fentiman of Cambridge University; and Mark Moshinsky, a barrister and academic from Melbourne, Australia. Messrs Fentiman and Moshinsky delivered papers at the Colloquium.

The commercial law academics and practitioners included Professor Roy Goode QC, a leading authority in the UK on commercial law and the Norton Rose Professor of English Law at Oxford University; Dr Joanna Benjamin, Deputy Chief Executive of the Financial Law Panel and author of The Law of Global Custody (both Professor Goode and Dr Benjamin delivered papers); Colin Bamford, Chief Executive of the Financial Law Panel; William Blair QC, a leading banking law practitioner and counsel to one of the defendant banks in the Macmillan case; Guy Morton of Freshfields; Edward Murray, a derivatives and collateral specialist at Allen \& Overy; senior banking lawyer, Hugh Pigott, from the Centre for Law Reform; Professor Dan Prentice, the Allen \& Overy Professor of Corporate Law at Oxford University; and Professor Barry Rider from the Institute of Advanced Legal Studies. In addition, Professor David Hayton, a leading authority on trusts law in the UK and the Head of the UK Delegation at the Hague Convention on the Recognition of Trusts in Private International Law, and Ravi Tennekoon, author of Law and Regulation of International Finance and international legal counsel to ABN AMRO Bank NV, were in attendance. 
An international legal perspective was provided by Professor James Rogers, principal draftsman of revised art. 8 and related sections of the UCC in the US and a presenter at the Colloquium; Randall Guynn, Chairman of the Committee on Modernizing Securities Pledging Laws of the Capital Markets Forum of the International Bar Association ${ }^{3}$; and Lawrence Wieman, a cross-border collateral transactions specialist at Davis Polk \& Wardwell in New York

Finally, experience of the practical and commercial considerations faced by financial institutions involved in collateralised loan transactions was available through Luigi De Ghenghi, Head of the Legal Department of Morgan Guaranty Trust Co of New York's at Euroclear Operations Centre; Patrick Harris of Goldman, Sachs \& Co; and Christopher Reich of Morgan Stanley \& Co

\section{MAIN ISSUE AND \\ FINDINGS}

Although a number of issues were discussed during the Colloquium, the principal issue facing the participants was as follows:

'Where book-entry interests in respect of a pool of fungible securities are held by an investor through a chain of financial intermediaries, which are located in a number of different jurisdictions, and the investor provides its interests in respect of the securities as collateral for a loan or other credit exposure, and then the investor purports to provide its interests as collateral to a third party, which law governs the proprietary aspects (i.e., the creation, perfection and priority) of such provision of collateral?'

This issue was considered both in general terms and with particular reference to the problem of identifying the law which should govern the characterisation of the collateral transfer of such interests by the investor ${ }^{4}$.

To focus the discussion, the following somewhat simplified hypothetical factual situation was considered at the Colloquium (for a schematic depiction, sce Figure 1 below):

(a) Victorian Investor holds interests in respect of Illinois Inc's securities (the 'Illinois Sccurities') through entries on the books of its financial intermediary, London Broker;

(b) London Broker, in turn, holds its interests in respect of the Illinois Securities through entries on the books of California Subcustodian;

(c) California Subcustodian, in turn, holds its interests in respect of the Illinois Securities through entries on the books of the principal central securities depositary for corporate securities in the US, Depository Trust Company ('DTC'), in New York;

(d) A nominee of DTC is recorded as the owner of the Illinois Securities on Illinois Inc's share register located in New Jersey at New Jersey Registrar;

(e) The certificates representing the Illinois Securities are physically held at Pennsylvania Depositary, a depositary for DTC in Pennsylvania.
Hypothetical Factual Situation Figure 1

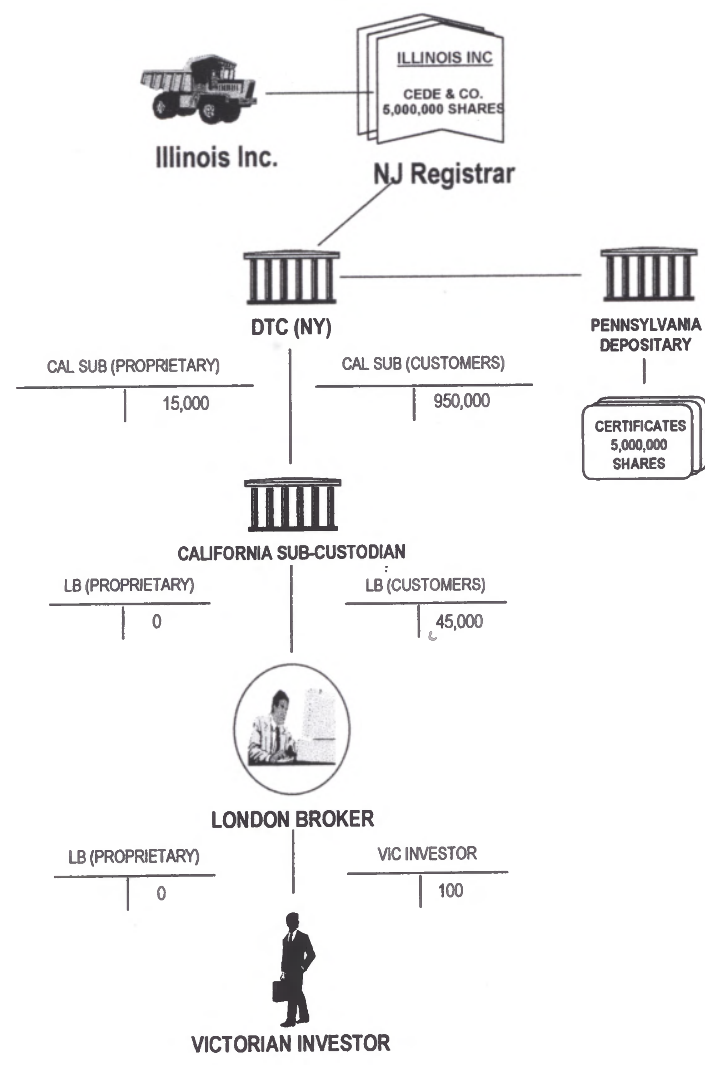


If Victorian Investor provides its interests in respect of the Illinois Securities to London Broker as collateral for a margin loan, and later purports to provide whatever interest it has in respect of the Illinois Securities as collateral to Third Party, which law governs the proprietary aspects of the provision of such collateral, such as the creation, perfection and priority of the interests, purportedly granted by Victorian Investor to London Broker and Third Party?

In general terms, there were two broad options considered by participants as the law to which proprietary questions should be referred:

(i) the law of the jurisdiction of the financial intermediary through which Victorian Investor's interests are held, i.e., the jurisdiction of London Broker (the 'place-of-theintermediary approach' ${ }^{5}$; or

(ii) the law where the underlying securities are 'located' (the 'placeof-the-underlying-securities approach'), which could mean the location of the register (New Jersey), the place of incorporation of the issuer (Illinois) or the location of any securities certificates (Pennsylvania).

Although participants expressed many divergent legal theories and practical considerations during the course of the Colloquium, one point of view stood out by virtue of its absence. Not one of the academics, practitioners or business people argued in favour of the place-ofthe-underlying-securities approach for interests in respect of securities held through a multi-tiered holding system. The reasons for this varied from the commercial inefficiency of applying such a rule to the fact that, in the case of intermediated book-entry securities, with the inherent commingling of interests at higher tiers of the multitiered holding system, it is no longer possible to link the investor to a particular allocated, underlying asset ${ }^{6}$.

The decision of the Court of Appeal in Macmillan was felt not to provide real guidance with respect to interests in intermediated book-entry securities because the court in Macmillan was not asked to consider the implications resulting from the custodianship of securities through a multi-tiered holding system.

\section{LEGAL THEORIES ADVANCED}

During the course of the Colloquium, the participants considered a number of approaches, all effectively pointing to the law of the place of the intermediary, London Broker, for the resolution of proprietary issues. Three participants endorsed variations of the traditional lex situs approach, while two other theories were considered that suggested a break from the traditional approach of attributing an artificial situs to intangibles.

\section{Lex situs approaches}

First, Mark Moshinsky suggested that the traditional lex situs approach deals adequately with multi-tiered holding patterns. Drawing on the work of Professor Goode and Dr Benjamin, Mr Moshinsky suggested that Victorian Investor's interest in respect of the Illinois Securities prior to the margin loan is one of beneficial co-ownership in the interests held by London Broker. London Broker is thus the trustee of a trust for the benefit of Victorian Investor (in fact, technically, it is rather a sub-trust arrangement with the sub-trust property held by London Broker being the security entitlement London Broker holds against California Subcustodian).

The proprietary aspects of the transfer (or relinquishment) of that interest would, under traditional conflict of laws principles, be determined by the lex situs of the interest. Relying on the current edition of Dicey \& Morris and certain cases, $\mathrm{Mr}$ Moshinsky argued that the appropriate conflict of laws rule for determining the situs of a beneficial interest under a trust is either the place of the underlying trust assets or the place of the trustee, depending on the nature of the beneficial interest. If Victorian Investor holds an absolute right to call on the trustee to deliver the trust assets in specie, then the beneficial interest is situated at the place of the assets; otherwise the situs is the place of the trustee.

Again drawing on Professor Goode's analysis, Mr Moshinsky noted that in the case of interests in intermediated bookentry securities, Victorian Investor does not hold any right to have the securities transferred in specie but rather only has the right to call for redelivery of equivalent securities (by the very nature of fungible securities, Victorian Investor cannot actually call for redelivery of particular securities). Consequently, $\mathrm{Mr}$ Moshinsky concluded that the situs of the beneficial interest is the place of the trustee; and by application of the lex situs rule, the law of the place of the trustee should govern. This view of the situs of interests under trusts was supported by both Professor Goode and Professor Hayton. In addition, Guy Morton supported the approach but suggested including express trust provisions in the documentation relating to the securities account, as well as language negating a right to delivery of any assets in specie; while not strictly necessary, this might provide helpful guidance for a court.

While concurring with $\mathrm{Mr}$ Moshinsky's analysis, Professor Goode also advanced a second argument for concluding that the situs of interests in intermediated book-entry securities should be the place of the intermediary. $\mathrm{He}$ contended that the underlying concept of the lex situs principle is the law of the place where the documents from which title is derived is located. This view is consistent, he pointed out, with the traditional notions that the situs of registered securities is the place of the register and the situs of bearer securities is the place of the certificate. Professor Goode noted that Victorian Investor has no direct claims against the issuer in relation to specific securities; instead, Victorian Investor has a proportionate interest in the fungible pool of securities held by London Broker. The source of Victorian Investor's interest is the entry on the books of London Broker - this is the 'document' constituting Victorian Investor's root of title. The situs of the interest in intermediated book-entry securities should be the location of the securities intermediary on whose books the interest is recorded ${ }^{7}$. Moreover, the co-ownership interest is located at the place of the securities intermediary, for it is enforceable there by proceedings against the securities intermediary as trustee.

Third, Joanna Benjamin suggested that it was helpful to see the rule in favour of the place of the intermediary as an aspect of the general rule of private international law, illustrated by much case law, that intangibles are notionally located where they are enforceable. The correct question is, 'Where can I find the record that determines my title?' 


\section{Moving away from the lex situs}

Two other approaches suggested at the Colloquium involved dispensing with the fiction of attributing a situs to an intangible thing

Professor Goode, although supporting the view that the lex situs approach, when applied to interests in intermediated book-entry securities, leads to the place of the intermediary, believed it analytically preferable to dispense with the legal fiction of a situs for such an intangible and go directly to the law of the place of the securities intermediary to govern such issues. He based this view on the very same reasons that led him and other Colloquium participants to conclude that the place of the intermediary was the proper situs of the interest. In the case of intermediated book-entry securities where there is no direct link with the issuer, the natural focal point for determining property rights is the place of business of the custodian. Professor Goode referred to legislation in Belgium, Luxembourg, the US and under art. 9(2) of the EU finality directive to support his contention that the trend internationally is in this direction.

Professor Reynolds, Richard Fentiman and Hugh Pigott argued for the law governing the relationship between Victorian Investor and London Broker (being the law gooverning the creation of the chose in action), which would often be the law chosen by the parties. In the US, the choice of the parties is respected under revised art. 8 and related sections of the UCC. Some participants objected to this approach on the ground that it would allow parties to a transaction to determine the law applicable to the rights of third parties and that this would not be appropriate. Others were unsure why fairness to third parties should be considered more important than fairness to London Broker, whose legitimate expectations might be defeated if the law governing its relationship with Victorian Investor were not applied. Such expectations might be of particular importance in disputes concerning the legal characterisation of any subsequent transfer of the latter's interest.

\section{Article 12 of the Rome Convention}

A question was raised as to whether art. 12 of the Rome Convention on the Law Applicable to Contractual Obligations has any relevance to proprietary questions. Professor Reynolds indicated that it was not clear that art. 12 should not be applied. If art. $12(2)$ is the predominant provision in this context (which is itself not certain), the applicable law is the law governing the creation of the chose in action and so will often be consistent with the place-ofthe-intermediary approach.

It is worth noting that Millett $\mathrm{J}$ at first instance in Macmillan [1995] 1 WLR 978, at p. 992, indicated that art. 12(2) has no relevance for property issues with respect to third parties. This is consistent with the view that art. 12(2) is only relevant for proprietary issues that concern a contracting party's disputes with the issuer of the securities and not to disputes that involve the rights of third parties, as is the case in the hypothetical fact situation.

\section{BUSINESS AND POLICY PERSPECTIVES}

Practitioners and commercial participants were very supportive of the various proposals, in that each led to a rule, the place of the intermediary, that provided a certain, predictable and practical answer to conflict of laws questions in cross-border collateral transactions. Patrick Harris explained that financial institutions involved in collateralised credit transactions are often at least as interested that the applicable rule be clear, certain and practical, so that commercial parties can arrange their affairs accordingly, as they are in the particulars of the rule itself.

A number of problems were voiced about any answer that would result in an application of the place-of-theunderlying-securities approach. First, there may be no certainty as to what the 'place of the underlying securities' actually means - the place of the share register (New Jersey), the place of incorporation of the issuer (Illinois), the place of the clearing system (New York for DTC) or the place of particular physical certificates (Pennsylvania). Secondly, the parties to a collateralised credit transaction are likely not to know, and are likely to be unable to determine expeditiously, where the underlying securities are in fact located. Thirdly, the usual situation facing the equivalent of London Broker is even more complicated than the situation in the hypothetical factual situation considered at the Colloquium. Rather than receiving as collateral its borrower's interest in respect of one issuer's securities, London Broker would typically receive portfolios consisting of interests in respect of securities of numerous issuers from different countries with daily turnover in the composition of the portfolio. Under such circumstances it becomes impractical, uneconomical and often impossible to determine, much less ensure compliance with, the laws of each and every one of these issuer's home countries or of the places in which all of the underlying securities certificates are located. Further, even a position in respect of a single issue of securities may be held through multiple chains or multiple intermediaries. With holdings fungible and usually commingled in omnibus accounts, it is not possible to separate different holdings. If Victorian Investor asks 'Where is my asset?' the only possible answer is 'At the location of London Broker.'

One concern raised was whether pensioners would be systematically worse off under a place-of-the-intermediary rule instead of a place-of-the-underlyingsecurities rule. Several participants expressed the view that there was no reason to assume that this would be the case. They believed that it was just as likely that any particular pensioner would be better off as worse off under either conflicts rule - i.e., both conflict of laws rules were probably neutral to the issue raised. Moreover, even if one of the rules was biased in favor of lenders, a view which none of the participants espoused, unit trusts, mutual funds and pension funds are just as likely to be lenders as borrowers. Because the wealth of most pensioners (except the super-rich) is increasingly tied up in unit trusts, mutual funds and pension funds, instead of individual securities holdings, pensioners as a group are likely to be better off (like everyone else) by the greater certainty and predictability afforded by the placeof-the-intermediary rule.

Professors Goode and Hayton thought that the concern raised was really a concern over intermediary risk, which is a separate issue from determining which conflict of laws rule to apply. They thought that the concern for intermediary risk was adequately addressed by the trust-like nature of a book-entry interest in respect of fungible securities. Because such an interest is proprietary and not merely personal, it is 
protected against the risk of the intermediary's bankruptcy. Others agreed, but thought that the proprietary nature of the rights involved could be supplemented by appropriate regulation of intermediaries, increased disclosure about intermediary risk and possibly insurance schemes for small investors (like deposit insurance).

\section{ENDNOTES}

1 There are no readily available figuresfrom official sources for the size of the collateralised credit market, but market professionals in a position to make an educated guess often estimate the current volume to be over \$US 1 trillion a day, growing at a rate of as high as $40 \%$ per annum. Transactions involving government securities account for the bulk of this volume. To put this in some perspective, the value of the collateral provided in one day can exceed the UK's GDP for 1997.

2 For example, in the US, during the liquidity crunch associated with the October 1987 stock market crash, Ernest T Patrikis, General Counsel to the Federal Reserve Bank of New York, attempted to determine whether banks and broker-dealers could confidently rely on security interests in intermediated book-entry securities, perfected under US law to make emergency loans to other banks and broker-dealers, and thereby help provide, liquidity to the system cluring the crisis. In response to his inquiries, Mr Patrikis often received not the assurance he had hoped for but the unsatisfactory response: 'That's a very interesting question.' To address, among other things, the unacceptability of such an answer, the US comprehensively revised art. 8 and related sections of its Uniform Commercial Code to provide such greater certainty.

3 In 1995, the International Bar Association committee issued four recommendations for international law reform to increase the certainty of crossborder collateral transactions. See 'No certainties about securities,' Financial Times, November 21, 1995, p. 15

4 The recharacterisation issue was addressed in papers by Joanna Benjamin and Richard Fentiman. There was general agreement that the characterisation of such a transfer, and in particular the question whether it represents an outright transfer of an investor's interest, is a matter for the law governing its proprietary aspect, whatever that law might be.

5 By this is meant the place of the investor's own intermediary. Hence, it may be more accurate (although more cumbersome) to refer to this as the 'place-ofthe-immediate-intermediary approach.')

6 For example, in the hypothetical factual situation outlined, no distinction on the records of California Subcustodian, DTC, Pennsylvania Depositary or New Jersey Registrar could be made between interests held for Victorian Investor, on the one hand, and those held for other customers of London Broker, London Broker itself (except at the level of London Broker's own intermediary, California Subcustodian) or other financial institutions, on the other hand.

7 Christopher Reich pointed out that it is important to make a distinction between the place at which the securities intermediary is located, i.e., its office or branch, which is generally evident to participants in a transaction and to the world at large, and the place in which the 'electronic data' of the securities intermediary are kept, presumably in a bank of computers that could be located in any number of places or in multiple places or, where networks are involved, in no single place at all. Consequently, he argued, it is important to refer to the law where the office of the securities intermediary maintaining the account is located and not the law where its computer bank or banks are located.

\section{Richard Potok}

Davis Polk \& Wardwell, London

This summary will form part of a special supplement to the Butterworths Journal of International Banking and Financial Law, which will include all papers presented at the Oxford Colloquium. The author is most grateful to the participants for their thoughts about the Colloquium and for their comments on various drafts of this summary; however, responsibility for errors and omissions rests with the author. (C) 1998 Richard Potock. 